\title{
Article \\ Schools, Universities and Large-Scale Assessment Responses to COVID-19: The Swedish Example
}

\author{
Marie Wiberg ${ }^{1, *(\mathbb{D})}$, Per-Erik Lyrén ${ }^{2}\left(\mathbb{D}\right.$ and Anna Lind Pantzare ${ }^{2}(\mathbb{D}$ \\ 1 Department of Statistics, USBE, Umeå University, SE-901 87 Umeå, Sweden \\ 2 Department of Applied Educational Science, Umeå University, SE-901 87 Umeå, Sweden; \\ per-erik.lyren@umu.se (P.-E.L.); anna.lind.pantzare@umu.se (A.L.P.) \\ * Correspondence: marie.wiberg@umu.se; Tel.: +46-90-786-95-24
}

Citation: Wiberg, M.; Lyrén, P.-E.;

Lind Pantzare, A. Schools,

Universities and Large-Scale Assessment Responses to COVID-19: The Swedish Example. Educ. Sci. 2021, 11, 175. https://doi.org/10.3390/ educsci11040175

Academic Editor: Kelum Gamage

Received: 19 March 2021

Accepted: 6 April 2021

Published: 8 April 2021

Publisher's Note: MDPI stays neutral with regard to jurisdictional claims in published maps and institutional affiliations.

Copyright: (c) 2021 by the authors. Licensee MDPI, Basel, Switzerland. This article is an open access article distributed under the terms and conditions of the Creative Commons Attribution (CC BY) license (https:// creativecommons.org/licenses/by/ $4.0 /)$.

\begin{abstract}
The aim of this paper is to describe, analyze, and discuss how Swedish schools and the national tests in schools, university teaching and examination, and the college admissions test, Swedish Scholastic Aptitude Test (SweSAT), have been affected by the COVID-19 situation. A further aim is to discuss the challenges in schools, universities and in the admissions test process in Sweden which are due to the COVID-19 situation. Contrary to many other countries, Swedish schools remained open, except for upper secondary school and universities where teaching went online. However, the spring administrations of the national tests and the high-stake college admission test, SweSAT, were cancelled, which had impact on admissions to universities in the fall. By using documentation from the news, school, and university authorities, as well as governmental reports of the events and a student survey, challenges are discussed. The novelty of this study includes a discussion of the events and their upcoming challenges. A discussion of what could be learned and what to expect in the close future is included, as well as conclusions which can be drawn from this situation.
\end{abstract}

Keywords: COVID-19; school response; university response; testing situations; testing challenges

\section{Introduction}

In the spring of 2020, schools and large-scale assessments were forced to adjust quickly to a new reality due to COVID-19. In Sweden, COVID-19 had a direct impact on most parts of the education and assessment systems, including universities and schools, as well as national tests in the schools and the college admission test, Swedish Scholastic Aptitude Test (SweSAT). The national tests are compulsory and are used as a means of fair grading. The SweSAT is optional but still high stakes, as it is used for selection to higher education. Candidates with a valid SweSAT score can be admitted on the basis of either upper-secondary school grades (GPA) or the SweSAT score, and they are placed in the selection group (GPA or SweSAT) that ranks them highest in the selection process. About 2/5 and 3/5 of candidates are selected on the basis of SweSAT scores and GPA, respectively.

The overall aim of this paper is to describe, discuss and analyze how Swedish schools and the national tests in schools, university teaching and examination, and the SweSAT in Sweden, have been affected by the COVID-19 situation. Both national tests in schools and the SweSAT were cancelled during the spring of 2020, leaving those who planned to apply for college and university in the fall of 2020 in a state of grave uncertainty. A further aim is to discuss the challenges in schools, universities and in the college admissions test process in Sweden that arose because of the COVID-19 situation.

Previous research of how higher education has been affected due to COVID-19 is currently limited, but there are some studies. Researchers have recently described the impact of the COVID-19 situation on large-scale assessments in the US [1]. Researchers have studied the perceptions of teachers and students on online teaching-learning modes 
and the implementation process of online teaching-learning modes [2]. Other researchers have studied the capacities of Georgia and its population to continue the education process online, and it reviews the different available platforms. They also report on what can be learned from quick online transition for future transitions [3]. Although there are also some studies of plans for using online or distance education tools during a crisis, these are focused on local crises and not a global one, such as COVID-19. Finally, countries with limited technologies are less likely to be sufficiently prepared to implement online education in the whole country [4]. Our paper is different from these papers, as it describes and discusses assessment and testing in the Swedish context, and our paper has a clear focus on the challenges that arose due to the pandemic.

We suggest that the Swedish example is interesting to a larger audience, as Sweden chose a different path in the pandemic and neither implemented a major lockdown of society nor cancelled in-person instruction for compulsory school (Grade 1-9). To keep the compulsory schools open in Sweden was a unique decision compared to the US [1] and many other European countries. However, during the second wave, in the fall of 2020, most countries decided to keep their schools open, at least for schoolyears 1-6, as school closure and home confinement might have negative effects on the mental and physical health of children [5]. A recent study has also shown that the psychological impact of quarantine is substantial and can be long-lasting [6].

The full impact of COVID-19 is still unknown. We do not yet know how learning and assessments will be affected, when instruction on campus will return to normal, and when exams can again be given in large lecture halls. Different adjustments are still in place both in schools, universities, and with respect to national tests and the college admissions test. Here, we will describe, analyze, and discuss the state of events up until 15 February 2021.

Besides from describing the COVID-19 impact, we will discuss challenges in schools, universities and those connected to the national tests and the SweSAT. More specifically, we will answer the following research questions:

1. How were Swedish schools, universities, and large-scale assessments, in terms of national tests and the SweSAT, affected by the COVID-19 situation?

2. What were the challenges for the undergraduate students, graduate students, and university teachers due to the COVID-19 situation?

3. What were the challenges associated with the transition to online education and testing?

The rest of the paper is structured as follows. In the next section we present the method used, followed by a description, analysis, and discussion of the impact of COVID-19 in schools and national tests, as well as challenges and possible solutions related to this. Then, the effects and challenges due to COVID-19 on the SweSAT are discussed and analyzed, followed by a similar account of the effect of COVID-19 on undergraduate and graduate university education and assessment. Finally, a discussion of testing in schools, universities, as well as large-scale testing in the future is provided, followed by some conclusions.

\section{Method}

To answer the first research question, we used newspaper articles, governmental reports and journal articles. To find these various sources, we used different search engines (including Google Scholar, the ERIC database, and ScienceDirect) and we talked to those in charge of the SweSAT and national tests, as well as to a member of the discipline authority. To answer the second and third research questions, we talked to 10 teachers, 5 graduate students, and conducted a survey among 45 undergraduate students. We also used search engines to find journal articles and governmental reports about the situation in schools and universities, as well as exploring challenges with online education and testing. 


\section{Impact of COVID-19 on Swedish Schools and National Tests \\ 3.1. The Swedish National Tests and the Swedish Grading System}

The national tests in Sweden aim to support an equal and fair grading process $[7,8]$. The Swedish national tests are one out of many other tests that help teachers to provide fair grades to students, thus, they are not to be seen as final exams. From 2018, however, teachers have had to pay special attention to the results from the national tests when grading their students [9] and, thus, they are high stakes for the students, as they heavily influence their final grades. National tests are given to pupils in grade 3 (Mathematics, Swedish), grade 6 (English, Mathematics, Swedish), grade 9 (English, Mathematics, Swedish, one of biology, chemistry, and physics, and one of civics, geography, history or religion). In upper-secondary school national tests are mandatory for students in their highest course in English, Mathematics, and Swedish.

All national tests are composed of different subtests. A few subtests are oral, but most subtests are paper and pencil tests, although they are planned to be computerized in a few years. The examinees take all subtests individually, there are no collaborative subtests or components. The subtests are given on certain dates and contain items that require responses in the form of multiple choice, short answers, essays, or complete solutions. Each subtest is administered to the whole age cohort, which is about 100,000 students.

The Swedish grading system is criterion-referenced and teachers are responsible for grading their students at the end of a course or at the end of a school semester. The grading scale comprises six steps: A-F, where F is a fail and A-E are different levels of pass, with A as the highest grade. When calculating the grade point average (GPA), the grade letters are assigned the following numeric values: $\mathrm{A}=20, \mathrm{~B}=17.5, \mathrm{C}=15, \mathrm{D}=12.5, \mathrm{E}=10, \mathrm{~F}=0$. The numeric values for each grade a student receives are summarized, and then an average is obtained by dividing the sum with the number of received grades in order to obtain a student's GPA. The grades in school-year 9, the last year in compulsory school, are used for admission to upper-secondary school. In the admission process to upper-secondary school, a majority of students enter their first choice [10]. The grades from upper-secondary school are used for both eligibility and selection in admissions to higher education. There is also a system with merit courses, where certain courses (e.g., modern languages and advanced mathematics) are worth extra points in the selection process. Hence, while the normal maximum GPA is 20.0, the maximum GPA for selection purposes is 22.5.

\subsection{Impact of COVID-19 in Swedish Schools}

On March 17, 2020, the Prime Minister of Sweden announced that upper-secondary schools were recommended to close and switch to distance education from the next day. Compulsory schools should remain open, but local authorities could decide to close a specific school if the spread of COVID-19 became too extensive. The reasons why Sweden, unlike almost all other countries, did not close compulsory schools were partly that children did not seem to drive the spread of infection, and also partly because children would retain their statutory right to education and parents could continue to work [11]. Recently published preprints of preliminary research results also support the hypothesis that younger children do not drive infection [12,13].

In Sweden, the vast majority of upper-secondary school students have a school computer, a prerequisite for the possibility of conducting distance education. Up to this time, however, the Education Act did not allow distance education and, therefore, schools and teachers were not prepared when schools closed. Still, when the Swedish Schools Inspectorate investigated how the transition to distance education had worked, after the first somewhat chaotic weeks, it seemed as it went quite well [14]. Most schools chose to follow a regular schedule in real time, and conduct teaching via various digital meeting platforms. To begin with, many students experienced that the workload increased, as the teachers required them to report what they had performed after each lesson. After a couple of weeks, the situation stabilized and teachers removed this type of reconciliation after each 
lesson [14]. In upper-secondary school, absence from school was slightly higher in the beginning, but overall absence actually turned out to be lower than normal [15].

Compulsory schools were, from one perspective, affected to a lesser extent, as teaching continued as usual. Still, absence rates, both among teachers and students, was greater than normal, partly due to the combination of regulations that you should stay at home if you have the slightest cold symptoms and the limited availability of COVID-19 testing [15].

The possibility of conducting distance education in compulsory school is more complicated, due to the fact that not all pupils have their own computers. In an investigation conducted in the autumn of 2018, only half of pupils in compulsory school have a school computer [16]. As most pupils in grades 7-9 have a school computer, the availability of computers is even lower among pupils in grades 1-6. Closing compulsory school had probably resulted in a situation where no teaching could have been conducted at all. Moreover, a general closure of compulsory school had probably meant that at least one of the younger children's parents would have had to stay at home to take care of the children.

Due to changed recommendations, pupils in compulsory school and students in upper-secondary school returned to school in the autumn of 2020. Yet, some restrictions remained, especially in upper-secondary schools. In order to reduce the number of students in corridors and school canteens, many schools had part-time distance education. In some schools, half of the students were on-site in even-numbered weeks and the other half were there in odd-numbered weeks.

Due to the increasing spread of COVID-19 in Sweden in the late fall, upper-secondary schools returned to full-time distance learning from the beginning of December. This time, however, students were permitted to come to school during practical course components and to take tests that could not be rescheduled.

\subsubsection{Problems Connected to Assessment and Grading in Schools}

One of the most common problems raised in the surveys connected to COVID-19 concerns assessment and grading [14,15], a problem that is more apparent in upper-secondary school, where students have studied from home to a large extent. In recent years, many schools have invested in some sort of digital assessment system to administer the schoolbased assessments, due to the requirement that, since 2018, the essays in national tests have to be written digitally. Due to COVID-19 and distance education, many teachers stated that it was very convenient to have access to these digital systems to administer assessments. However, many teachers expressed concerns about the obvious risk of cheating [14]. According to the surveys conducted by the Inspectorate and the National Agency of Education, teachers have been highly creative $[14,15]$. A common solution was to deliver the test through a locked digital assessment platform, and proctor the students via a mobile phone from which the students log in to a digital meeting room with video and a microphone to show what they are doing. Normally, one teacher proctored a whole class with 25 to 30 students, which is more than recommended [1]. Some teachers stated that, when they suspect cheating, they ask supplementary oral questions [14]. In addition, in some subjects such as mathematics, students have come to school and completed tests in small groups.

\subsubsection{The Cancelation of the National Tests}

In the spring of 2020, all national tests with test dates from the beginning of March were cancelled. The reason for canceling the national tests, although the schools were not closed, was that, since the national tests are rather high stakes, there was an obvious risk that students with mild symptoms would attend. Furthermore, as upper-secondary schools had distance education, it would have been necessary for students to come to schools at the test dates, which could have increased the spread of the disease.

The annual report on national school statistics from the National Agency of Education shows that the proportion of pupils who are eligible for upper-secondary school increased in the spring of 2020 [17]. Some have argued that the increase in grades is due to the fact that students had more teaching time when the national tests were canceled, while others 
have stated that the absence of national tests meant that there was nothing to relate to except the teachers own assessments. The raise in the grades is, however, quite small, and it is therefore difficult to conclude if the raise is only due to natural fluctuations or if teachers have taken the opportunity to reward students.

After schools opened up in the autumn of 2020, with more or less on-site teaching, national tests for upper-secondary schools were given in the fall of 2020. For compulsory schools, only the oral parts have testing dates in the autumn. A couple of days before the Christmas vacation in 2020, the National Agency of Education declared that the spring 2021 administration of all national tests was cancelled.

\subsection{Challenges for School Assessments and the National Tests}

When administering school assessments, Sweden has no tradition of using remote proctoring. Remote proctoring, or online proctoring, means to use either human proctors or automated processes to monitor the delivery of a digital assessment through microphone and web camera using the internet. Remote proctoring was introduced in large-scale assessment by Kryterion in 2008 [18]. If a human is used, the recommendation is to not monitor more than 16 students. If monitoring software is used, artificial intelligence (AI) is often used to monitor the test takers' behaviors. The AI algorithm searches to identify sounds, interruptions, suspicious movements, and whether an extra individual appears. Disruptive behaviors are flagged and the recorded movie could then be seen afterwards by a human. However, closure due to the pandemic revealed the need to be able to administer tests remotely, and to be able to proctor students. The digital assessment systems available for teachers to use can lock down the computer, but the system cannot know if students have someone else or another digital device in the room that can help them to solve items. The risk of cheating is therefore high.

In the case of the national tests, one challenge is the increasing risk of cheating due to remote administration. Since the national tests are rather high stakes, the incentive for cheating is high. A second challenge is that, when using remote administration, fairness issues are introduced. Even if most students, at least in upper-secondary school, have a school computer, they might not have a good internet connection or a room at home where they can close the door and be alone.

A third challenge is how to organize proctoring now and in the future. The Swedish school system is based on the premise that teaching and assessment takes place at schools. Thus, there has not been a need to develop systems with remote proctoring during assessments. It is also much easier to use human proctors in schools, since that is where students normally are. During the past few years, work has begun on computerizing the national tests so they can be administered digitally in a few years. A new digital assessment platform is under construction and, at the same time, digital test items are being developed. Human proctors are planned to be used and there is currently no plan to include any remote proctoring option in the assessment platform.

\section{Impact of COVID-19 on the College Admissions Test SweSAT}

\subsection{The SweSAT}

The SweSAT is a large-scale assessment which is normally administered twice a year-one time in the spring (usually early April) and one time in the fall (usually late October). The test is optional and the test taker can repeat the test as many times as she or he likes, and only the best result is used when applying for university. A SweSAT score is normally valid for five years. The test is typically administered to 40,000-70,000 test takers each administration, with more test takers in the spring than in the fall. It contains a verbal and a quantitative section, each containing four subtests. The verbal subtests are Swedish vocabulary, Swedish reading comprehension, Swedish sentence completion, and English reading comprehension. The quantitative subtests are diagrams, tables and maps, mathematical problem solving, data sufficiency, and quantitative comparisons. Each subsection contains 80 items, and the subsections are equated separately and placed on a 
scale from 0.0 to 2.0 , with step increments of 0.1 . This scale is constructed so that a score of, for example, 1.2, means the same regardless of which SweSAT administration it comes from. The verbal and quantitative scaled scores are averaged into one SweSAT score with a range from 0.00 to 2.00 , with step increments of 0.05 . For more information about the SweSAT and the Swedish admissions system, see [19].

\subsection{Impact of Cancelling the Spring 2020 Administration of SweSAT due to COVID-19}

The spring 2020 administration on April 4 of the SweSAT was cancelled on March 13 due to COVID-19. This decision brought about one immediate change, namely that the period of validity of SweSAT scores was increased from five to eight years. Because the pandemic caused large unemployment, the number of applicants to university increased by 13 percent in the fall of 2020, while the admitted candidates increased by 10 percent when compared with the fall of 2019; this means that, in general, competition was higher. Yet, the Swedish Council for Higher Education (hereafter referred to as the Council) concludes that cancelling the spring SweSAT administration seems to have had little impact on the chances of being admitted, when looking across all available programs and courses. However, as will be discussed later, the cancellation of the SweSAT appeared to have had an impact on the possibility of students getting into a university program of their choice.

\subsection{The 2020 Fall Administration and 2021 Administrations of the SweSAT}

The legislation surrounding SweSAT complicates decision making, as the Council is responsible for the test itself, 21 higher education institutions are responsible for the test day administration, and the Government (Department of Education; Stockholm, Sweden) is responsible for general regulations. Discussions between these three units about the fall administration of the SweSAT were lowkey during the spring and summer, but became intensified and highly political later on. The national university union magazine, Universitetsläraren [20], published a timeline of these events and this is displayed in Table 1, with some additions and edits for context and clarification, including a decision on 2021.

The different events in Table 1 led to an administering of the SweSAT in the fall of 2020 to a limited number of test takers in order to enable physical distance. From the event time line, it is noticeable that the Council did listen to the administrating institutions, as two limitations were put into place: (1) the test was only open for those who did not already have a valid SweSAT score, and (2) there was a cap on the number of test takers in each administrative region, which summed up to 27,600 seats nationally. As repeated test taking is common for the SweSAT (about 50 percent of the test takers in each administration has taken the test before), the first limitation alone had a large effect on the number of test takers. The 27,600 seats can be compared to the $40,000+$ people who took the test in the fall of 2019. In the end, about 26,600 signed up for the test and close to 24,000 people ultimately took the test. The impact of the limitations on the composition and performance of the test takers was, when compared to the fall 2019 test-takers, a relatively large proportion of test takers under the age of 21 (69 percent compared to 64 percent) and over the age of 30 (11 percent compared to 7 percent), and a relatively poor performance, with an average score of 0.84 (compared to 0.89 in the fall of 2019), which corresponds to a difference of 0.13 standard deviations.

As stated in Table 1, there will be two spring administrations of the SweSAT in 2021. This was decided to provide test taking opportunities for more people while, at the same time, providing better possibilities for physical distancing. There will be two limitations: (1) an age limit of 19 years of age (or a certificate that the candidate is in the final year of upper-secondary school), and (2) a cap on the total number of test takers at 70,000; that is, 35,000 per administration. The sign-up period started on the 12 January 2021, with test administrations on March 13 and May 8. The fall administration of 2021 has not been publicly discussed yet, but anything other than a single test administration seems unlikely at this point. The Council has assigned the test developers, Umeå University and 
Gothenburg University, to produce three test forms during 2021, so, with the extra test administration in the spring, there will only be one test administration in the fall.

From the events in Table 1 it is obvious that access to higher education is highly political, and one should keep this in mind if future administrations are threatened. A lesson learnt is the importance of preparing for possible future interruptions when SweSAT cannot be administered as planned; for example, to lift the responsibility of administrating the test from the administrative institutions to a higher decision level which can take full responsibility. One should also evaluate the currently imposed restrictions of test taking and examine the upcoming year's admissions in order to make sure that restrictions do not impose unfairness between certain groups. Depending on the outcome of such examinations, one should have a plan prepared for possible interruptions of future SweSAT administrations.

Table 1. Timeline of the events that led to administering SweSAT in the fall of 2020 and spring of 2021.

\begin{tabular}{|c|c|c|}
\hline Date & Organization & Event \\
\hline $24 / 4$ & Council + institutions & $\begin{array}{c}\text { Meeting regarding the conditions surrounding the fall } \\
\text { administration }\end{array}$ \\
\hline $25 / 5$ & Council & $\begin{array}{l}\text { Submits a memo to the Government regarding the } \\
\text { possibility of limiting the number of test takers. }\end{array}$ \\
\hline $30 / 6$ & Council & $\begin{array}{c}\text { Receives information that the Government moves forward } \\
\text { with the issue of limitations and its corresponding need for } \\
\text { changes in the Higher Education Ordinance }\end{array}$ \\
\hline $9 / 7$ & Government & $\begin{array}{l}\text { Does not intend to make changes in the ordinance (i.e., the } \\
\text { Council cannot limit the number of test takers). }\end{array}$ \\
\hline $20 / 7$ & Council & $\begin{array}{l}\text { Are assigned, from the Government, to investigate the } \\
\text { prerequisites for administering the SweSAT in the fall of } \\
\qquad 2020 \text {. }\end{array}$ \\
\hline $6 / 8$ & Council & $\begin{array}{l}\text { Presents the prerequisites for administering the SweSAT in } \\
\text { the fall of } 2020 .\end{array}$ \\
\hline $7 / 8$ & Council & Decides to cancel the fall administration of the SweSAT. \\
\hline $19 / 8$ & 3 political parties & $\begin{array}{l}\text { Writes a debate article, demanding that the SweSAT shall be } \\
\text { administered in the fall of } 2020 .\end{array}$ \\
\hline $27 / 8$ & Government & $\begin{array}{l}\text { Decides about changes to the Higher Education Ordinance } \\
\text { regarding limitations to the number of test takers. }\end{array}$ \\
\hline $31 / 8$ & $\begin{array}{c}\text { Institutions } \\
\text { (Vice-Chancellors) }\end{array}$ & $\begin{array}{l}\text { Write a debate article where they argue that the risk of an } \\
\text { increased spread of COVID-19 during the SweSAT test } \\
\text { administration day is far too great, even with a limited } \\
\text { number of test takers. }\end{array}$ \\
\hline $1 / 9$ & $\begin{array}{l}\text { Parliament's education } \\
\text { committee }\end{array}$ & $\begin{array}{l}\text { With an initiative from the three political parties, a meeting } \\
\text { is held aimed at putting pressure on the Government to } \\
\text { enable a test administration in the fall. }\end{array}$ \\
\hline $1 / 9$ & Liberal party & $\begin{array}{c}\text { Backs on the initiative and a majority of the committee says } \\
\text { no to a SweSAT administration in the fall }\end{array}$ \\
\hline $8 / 9$ & Government & $\begin{array}{l}\text { Announces that a "national coordinator" will be appointed } \\
\text { to help the Council make sure that the SweSAT can be } \\
\text { administered in the fall. The responsibility for } \\
\text { administering SweSAT is transferred from the admin to the } \\
\text { Council. }\end{array}$ \\
\hline $9 / 9$ & Council & The Director General of the Council resigns. \\
\hline $17 / 9$ & National coordinator & $\begin{array}{c}\text { Announces that the fall } 2020 \text { administration of the SweSAT } \\
\text { will take place on October } 25 \text {, with participant registration } \\
\text { on a first come, first served basis }\end{array}$ \\
\hline $10 / 12$ & Council & Announces two spring administrations 2021 of the SweSAT. \\
\hline
\end{tabular}

Note. Institutions = the 21 universities and university colleges in charge of administering the SweSAT; 3 political parties $=$ three political parties from the opposition: M (Moderate Party), L (Liberal Party) and KD (Christian Democrats). 


\subsection{Comparison of SweSAT and Its Use in College Admissions Compared with ACT and SAT in US}

In the US, most students normally complete the college admissions test SAT and ACT at school-based test centers-distributed seven or eight times a year. Due to US school closures, the May and June SAT administrations and the April ACT administration were cancelled. Similar to SweSAT, many test takers repeat ACT and SAT: the first time in the spring of the junior year and the second time in the fall of the senior year. In 2020, ACT was administered to about 55,000 students at several smaller test centers that opened in June, and they have continued testing with reduced seating. In a normal year, about 300,000 test takers register to take the ACT and SAT on each of the national testing dates (March, April, May, and June). Due to school closures, about one million juniors may not have been able to take the test as planned in the spring 2020. However, as admission to university is centralized in Sweden, the SweSAT scores are valid for several years and have continued to be used during the pandemic. This is the opposite to a number of universities in the US, which have decided that valid ACT or SAT scores are not needed in the near future [21].

\subsection{Challenges for the SweSAT}

An important question for the future is how to administer large-scale, high-stakes tests like the SweSAT during a pandemic such as COVID-19. The main challenge for the SweSAT is that the current form of administration (paper-based, linear/fixed form) presupposes many people taking the test at the same time, which, in turn, leads to crowding. To prevent crowding, the test taker cohorts need to be spread out over time, and, to do this, there need to be more test forms. Producing more fixed test forms can be done to some extent, but, at some point, there will be too few test-takers per test form to be economically justifiable and to maintain a sufficient volume of item pretesting. Consequently, introducing some level of adaptivity in test delivery is probably necessary, and the only feasible way to do this is through computerization.

Another way of preventing crowding is remote test administration, where candidates take the test at home, for example. This could be possible in theory, but it is not practically feasible with a paper-based test, as it would be virtually impossible to implement sufficient security measures. Consequently, the solution seems to be delivery via computer. Computerization of the SweSAT was recently subject to investigations by the Council. The final report [22] came out in 2019 and concluded that, in the long term, there is a need to computerize the SweSAT. There are, however, currently no plans to start the computerization process, as there are several challenges connected to computerization, especially how to deliver the test to a large number of test takers at a certain date and time.

\section{Impact of COVID-19 on Universities in Sweden}

\subsection{Application to University Programs}

Most students apply to higher education in April and receive notification of acceptance during the end of July. Only a small number apply in the fall to start in January. In the fall of 2020, there was a large increase of applicants, which is probably due to higher unemployment rates and a more uncertain future in work areas such as restaurants, hotels, tourism, and entertainment. Table 2 illustrates the number of applicants to some of the most popular university programs, and the last admitted student's GPA and SweSAT score at the largest university in northern Sweden in 2018 and 2020. Note, the pattern is similar for other university programs. From Table 2, it is evident that the GPA is overall similar but the SweSAT score is much lower for all programs, except for the nursing program. The lack of the spring administration of SweSAT 2020 is probably the reason for the lower required SweSAT admissions score. The fact that the nursing program had a higher SweSAT score might be an effect of media coverage of nurses working during COVID-19, which made the program more attractive than before. Overall, there were more applicants in the fall 2020 than in the fall 2018 and 2019. 
Table 2. Number of applicants (N), the last admitted student's grade point average (GPA), and the last admitted student's SweSAT score for different university programs in the falls of 2018 and 2020.

\begin{tabular}{ccccccc}
\hline \multirow{2}{*}{ University Program } & \multicolumn{2}{c}{ N } & \multicolumn{2}{c}{ GPA (B1) } & \multicolumn{2}{c}{ SweSAT } \\
\cline { 2 - 7 } & $\mathbf{2 0 1 8}$ & $\mathbf{2 0 2 0}$ & $\mathbf{2 0 1 8}$ & $\mathbf{2 0 2 0}$ & $\mathbf{2 0 1 8}$ & $\mathbf{2 0 2 0}$ \\
\hline Medical & 629 & 677 & 21.61 & 21.77 & 1.65 & 1.55 \\
Law & 450 & 467 & 20.13 & 20.21 & 1.30 & 1.20 \\
Psychology & 375 & 429 & 21.61 & 21.35 & 1.60 & 1.45 \\
Nursing & 238 & 309 & 17.90 & 17.90 & 0.70 & 0.80 \\
Economy & 268 & 299 & 17.50 & 17.50 & 1.10 & 0.90 \\
Social work & 370 & 253 & 17.81 & 17.49 & 0.85 & 0.75 \\
\hline
\end{tabular}

\subsection{On-Campus and Online Teaching}

During the fall of 2020, all Swedish universities went back to some on-campus teaching, although the majority of teaching and examination was still performed online. To justify these openings, a huge COVID-19 testing was conducted at Umeå University, the largest university in northern Sweden. All $(4062)$ employees and all $(34,407)$ students with a valid Swedish social security number and electronic identification app (bankID) were invited to test for COVID-19 in the first week of instruction, and a follow up test one week later. A total of 9907 participants were tested, of which 6703 were tested on both occasions. Among those who were tested, about $2 / 3$ were students and the rest were employees. Almost all participants had been in Sweden for the past two weeks, and about $40 \%$ outside of the region (n.b., Sweden is divided into 21 regions). Only six participants were found positive [23]. It was concluded that, at this time, there were very few who had the disease, and it was also concluded that opening up a university campus with social distancing restrictions tends not to be immediately dangerous. These are probably interesting results for the international community, as many campuses around the world hesitated to open up campus for students, and, instead, only used online instruction; for example, California State Universities, California Community Colleges, and a number of other colleges and universities.

In Sweden, the decision of how much instruction is given at campus and online during the pandemic differs between universities. Furthermore, the restriction rules differ between schools and universities. This is similar to the US, where these kinds of decisions for schools and colleges are made at the regional level, or by individual institutions, when it comes to higher education [1]. As the rules differ between schools and universities, it may cause problems or be otherwise challenging for some students.

\subsection{Challenges for Undergraduate Students, Graduate Students and Teachers}

All teaching and examinations were moved from campus to online due to recommendations from the national health authority on March 17, and most universities made the transition directly, so it was in effect on March 18. Different universities decided upon their own rules and guidelines, and this was the case when some universities decided to open their campuses again in the fall of 2020. Most teaching was moved to the Zoom platform, but examinations could either be live on Zoom or on a web-based platform, such as Canvas. There were several challenges in moving from campus to online teaching and testing for undergraduate students, graduate students and teachers, and these challenges are labelled A-F and later summarized in Table 3.

Challenge A concerns home work environment and living situation. If a student or teacher lives by themselves and has a good working place and no one around, they may get a lot of work done. Undergraduate students more often live by themselves than graduate students and teachers, and, thus, this might be less challenging for them. However, graduate students and younger teachers are often young adults, and it is not uncommon that they are parents with small children. Thus, although it is recommended from a health perspective to work from home, it may be very challenging for those who do not have access to a quiet workplace. This challenge also includes the physical home work 
place setup, such as screens, an office chair, and good lighting. This challenge is difficult for universities to handle. A possibility in the future would be to have small rooms that can be booked at university facilities for those students who do not have a good home work environment.

Challenge B concerns social environment. Undergraduate students usually belong to a class and, unless they are a freshman, they know their classmates and, thus, can keep in contact online. Group assignments can also help enforce the social environment. Graduate students in Sweden typically only follow a few classes with few students, and are used to working alone or in small research groups. To move everything online might, thus, be more socially isolating, especially as department colleagues work from home. This is particularly challenging when one needs to start building a work network and conferences are cancelled (e.g., FREMO in Norway), postponed (e.g., Compstat in Italy), or moved from in-person meetings to virtual meetings (e.g., AERA in the US). On the other hand, it might be cheaper to attend virtual conferences, thus, the project leader may allow the graduate student to attend more conferences than if they were to attend on site. As there are no student fees for higher education in Sweden, students have more choices of online courses from other universities. In the future, one should consider keeping some of the theoretical courses online in order to attract more students, and to give students more available courses, especially at graduate level.

Challenge $\mathrm{C}$ concerns the receiving and giving of teaching online versus in-person. An undergraduate student may feel a greater disconnect from their teachers, and the devices they have access to may influence their learning or how the material is perceived. Teachers may have a harder time to assess whether students understand their teaching in cases where students do not have their cameras on, because this leads to less teacher-student interaction. In the future, one should think of when cameras should be on or off and when smaller group assignments should be used to enhance social interactions. One could also consider alternative teaching forms, such as noted by [24], which could possibly be used with online teaching.

Challenge D concerns exams, especially in large undergraduate courses. Before COVID-19, most undergraduate exams and some graduate exams were taken in large lecture halls at certain dates and times. To use online exams is challenging, as students face a disadvantage relative to students who take exams in a traditional, proctored environment; this is because of the absence of a proctor who can provide clarifications on exam questions, the possibility of greater distractions in the home environment, and possible problems with internet connections and the students' computers [25]. For teachers, it may also be difficult to provide exams that are difficult to cheat on, or where answers are difficult to find with search engines. In the future, one should think of different ways of providing exams to students at different levels.

Challenge E concerns cheating, especially in undergraduate courses, as online testing facilitates cheating [26]. Different strategies can be used to prevent cheating, such as forcing the students to keep web cameras and audio on. A problem with keeping audio and video on is that unwanted noises and interruptions in privacy may be a larger problem for some students, if all students are online at the same time. Even if microphones and audio are on, there is a challenge of controlling the home environment. This includes which material the student may have access to, but, also, access to a quiet room with no interruptions of other individuals (Challenge A). Unless some kind of remote proctoring is used, it is difficult to ensure that students do not send cell phone photos of answers to their peers. Using human proctors is a possibility, but is challenging in large courses, as one may lack available staff.

Each university in Sweden typically has a discipline authority which handles potential cheating cases. The number of cheating matters in one university between 2015 to 2020 has been relatively constant (2015: 71, 2016: 100, 2017: 88, 2018: 60, 2019: 94: 2019 1/1-8/9: 53, 2020: 1/1-8/9: 52) as only about $0.2-0.3$ percent of all students end up with a cheating matter in the discipline authority. Up until 2019, most of the matters were students with cell phones making sounds in jackets or bags during on-campus exams, which resulted in a 
warning. During 2020, all these kinds of matters were almost nonexistent, as no on-campus exams were given from mid-March. Instead, the matters concerned plagiarism, cheating, copying, or sharing solutions [27]. In the future, we need to work more proactively to reduce cheating and make students realize the problems with cheating.

Challenge $\mathrm{F}$ is to what extent it is possible to finish planned projects or compulsory course components. Some undergraduate students were affected in terms of practical parts of their education. Many graduate students and teachers with research projects have projects that require in-person meetings. In the COVID-19 situation, they have experienced delays with their projects, and some have been required to change or even cancel their projects. Although changing a research project may mean that the project takes a longer time, at this point, there are no general study time extensions for graduate students due to COVID-19 [28]; although, it is likely that several individual adaptions will be required within a close future.

Table 3. Challenges for undergraduate students, graduate students, and teachers.

\begin{tabular}{|c|c|c|c|}
\hline & Undergraduate & Graduate & Teachers \\
\hline $\begin{array}{l}\text { A. Home work } \\
\text { environment }\end{array}$ & $\begin{array}{c}\text { Lives with another } \\
\text { adult and/or children } \\
\text { (less likely). }\end{array}$ & $\begin{array}{l}\text { Lives with another } \\
\text { adult and/or children } \\
\text { (more likely). }\end{array}$ & $\begin{array}{l}\text { Lives with another adult } \\
\text { and/or children (more } \\
\text { likely). }\end{array}$ \\
\hline B. Social & $\begin{array}{l}\text { Belongs to a class. } \\
\text { Group assignments. }\end{array}$ & $\begin{array}{l}\text { Attends small classes. } \\
\text { Usually works alone. }\end{array}$ & $\begin{array}{l}\text { Lack of in-person } \\
\text { interaction. }\end{array}$ \\
\hline C. Teaching & $\begin{array}{c}\text { Receives online } \\
\text { teaching. }\end{array}$ & $\begin{array}{l}\text { Receives and provides } \\
\text { online teaching. }\end{array}$ & Provides online teaching. \\
\hline D. Examination & $\begin{array}{l}\text { Written assignments. } \\
\text { Online exams. } \\
\text { Group work. }\end{array}$ & $\begin{array}{l}\text { Written assignments. } \\
\text { Online exams. } \\
\text { Grade undergraduate } \\
\text { exams. }\end{array}$ & $\begin{array}{c}\text { Constructs and grades } \\
\text { undergraduate and } \\
\text { graduate exams. }\end{array}$ \\
\hline E. Cheating & $\begin{array}{l}\text { More common with } \\
\text { online exams. }\end{array}$ & Uncommon. & $\begin{array}{l}\text { Constructs exams to } \\
\text { minimize cheating. }\end{array}$ \\
\hline F. Work/Studies & Practical parts. & $\begin{array}{l}\text { Time limited projects. } \\
\text { May require in person. }\end{array}$ & $\begin{array}{l}\text { Time limited projects. } \\
\text { May require in person. }\end{array}$ \\
\hline
\end{tabular}

\section{Challenges of Remote Testing in Schools, SweSAT and Universities}

Regardless of whether a student is in school or at university, the challenges of remote testing are similar. The large-scale assessments in the US, such as the GRE General Test, Test of English as a Foreign Language (TOEFL), iBT Test, Graduate Management Admissions Test (GMAT), and Law School Admissions Test (LSAT), all cancelled in-person testing due to COVID-19, and, instead, used different remote proctoring solutions [1]. The use of remote proctoring software has not been used to any extent in Sweden during the pandemic. Common solutions are instead to use recorded test sessions (video and audio) and human proctoring.

Challenge A concerns the delivery of a digital examination. This includes the quality and the speed of the internet connection at students' homes. It could be viewed as unfair if some students only have a smaller amount of streaming, paid for by their parents or themselves, compared with those who have unlimited streaming services. This is probably more problematic in the US than in Sweden as, according to a US survey described in [1], only $35 \%$ of participants stated that their internet connection was great, $53 \%$ stated that it was ok, and $14 \%$ stated that it was terrible/unpredictable. In the large-scale assessment Trends in Mathematics and Science Study (TIMSS) 2015, 99\% of the examined grade 8 students in Sweden had access to internet connection [29], but the quality of the connection (fiber vs. mobile) and how much streaming they have access to might be a reason for unfairness among different social groups, as would whether they live in a city or in the countryside [30]. One study [31] concluded that test takers who take a computerized test instead of a paper and pencil test are not disadvantaged. Others [18] found, when controlling for school and student background, that students who took a test in a paper and 
pencil format scored higher than students who took the test online. Thus, if the students are able to choose how to take a test, this might create unfairness. A person in a risk group may prefer to take a test online even if it may be disadvantageous compared with a paper and pencil test. Furthermore, students with disabilities may find it more difficult with digital exams. There is also a question of how much extended time one should provide (e.g., $50 \%$ or $100 \%$ extended time). In addition, to deliver a high-stake test like SweSAT at two particular dates each year means that nothing is allowed to go wrong during those days. There must be a backup system and plans for how to handle, for example, a loss of internet connection.

Challenge $B$ is the large variation of devices that students use to take the test. The differences concern platforms, on-screen tools, screen-sizes, and screen quality. Depending on devices used, the test may be more or less difficult for the test taker. In compulsory school, this can be controlled by giving each student a school device. As this cannot be controlled in higher educational levels or the SweSAT, one needs to be careful which platforms to use, and how the test is set up, so that the test is fair regardless of the device used.

Challenge $C$ is similar to Challenge $A$ for university students and teachers, and concerns students' home environment in terms of access to quiet places, study desk size, and a private room. According to the TIMSS 2015 survey data of Swedish eighth graders, $95 \%$ had a study desk and $93 \%$ had their own room [29]. Schools or universities cannot control a student's home environment, but they could have small rooms that can be booked for exams in the future.

Challenge D concerns privacy and integrity during online testing-for example, when using cameras and microphones to scan the room and record a student testing session. A disadvantage with remote proctoring is a problem with personal integrity [32,33]. Although some countries, such as the US, use this, the Swedish Authority for Privacy Protection has concluded that the EU general data protection regulation (GDPR) cannot be fulfilled if one is using remote proctoring software [34]. We conducted a survey among 45 undergraduate students, in November 2020, about online teaching and digital testing of a university course taking elementary statistics. The answers revealed that about $37 \%$ believed that their studies had been affected negatively, and $49 \%$ thought it was negative to have a digital examination in comparison to an in-person classroom examination.

Challenge E concerns the higher risk of cheating associated with online testing, and this overlaps with Challenge $\mathrm{E}$ for undergraduate and graduate students. For example, the issue of identification is problematic if one is using an electronic ID app on one's cell phone (e.g., bankID), as one does not want students to have cell phones during a test. There might also be interactions between students, both live and digitally, which are difficult to control for. An advantage of remote proctoring is that it helps in detecting cheaters [32,33]. However, one problem with remote proctoring in large-scale assessments, such as SweSAT, is the large number of proctors that would be needed on a single test occasion.

\section{Discussion}

The full effects of COVID-19 on schools and large-scale assessments are yet to be seen, but the experiences gained from the pandemic should be considered when forming the future of large-scale assessments and examinations in upper-secondary schools and higher education. The first research question concerned how Swedish schools, universities and large-scale assessments, in terms of national tests and the SweSAT, were affected by the COVID-19 situation. The impact on compulsory schools was limited, as they remained open the whole time, contrary to many other countries, including the US [1]. During the second wave, most countries did as Sweden did and kept their schools for lower grades open, with the motivation that young children do not drive the infection [13,14], and school closure and home confinement might have negative effects on the mental and physical health of children [5]; there was also the question of the psychological impact of quarantine, which is substantial and can be long-lasting [6]. This is an important lesson, because, if 
schools are closed, fewer adults can go to work and, thus, the impact on society is greater. Many young children would also be disadvantaged, since not all families have the means to conduct distance education, and lower-grade students typically do not have a digital school device.

Upper-secondary school and universities were heavily affected, as most teaching moved online from one day to another. A strength was the fact that Sweden is a high technology country, which made it quite easy to adapt to online teaching, as opposed to countries with limited technologies [4]. A facilitating fact is also that most Swedish students have access to a computer and internet connection [29,30]. Sweden also has a history of remote higher education due to local politics, to facilitate for people who lose their jobs to educate themselves to get another job without moving. Thus, most Swedish universities already had some courses that were completely taught online before the pandemic, and this probably facilitated the transition. A weakness was, however, that on-campus students were not prepared for the situation and, in the future, it is important to examine the impact of this transition for different groups of students, so no group is disadvantaged.

National tests were cancelled, and that could have affected students' final grades, as they are used to support a fair and equal grading between schools. As noted in [35], there is already a difference between schools, and it is possible that the cancelation of the national tests made the difference even larger. A weakness is that the organization was not prepared, and, if we want to maintain a fair grading system, we also need well-functioning tools under extraordinary circumstances. A strength is that the national tests will soon be computerized, and that could probably prevent them from being canceled during a pandemic in the future.

In Sweden, the selection quota groups for university admissions have still not changed; even though the spring administration 2020 of SweSAT was cancelled, the fall 2020 administration of the SweSAT was limited, and teaching is still digital for many students in upper-secondary schools. The cancellation of the SweSAT spring administration had an impact, as the admissions showed that it was easier to get into some high-profile university programs if one had a valid SweSAT score. Leaving the quota groups unchanged is different from how it was performed in the US, where more than 50 percent of the 3330 four-year colleges and universities will not require applicants to submit test scores from their college admissions tests, ACT or SAT, for the 2021-2022 admissions cycle, including a majority of the liberal arts colleges. Several institutions have also made it optional for a limited period of time [1]. In the future, a preparation for disruption of a single testing date per semester (national tests, SweSAT) might be needed, as other threats may disrupt a testing occasion (such as security threats, which may require different forms). COVID-19 may be the catalyst for moving some tasks permanently in a digital direction.

The second research question concerned the challenges for undergraduate students, graduate students and teachers in universities due to the COVID-19 situation. From the conducted survey and interviews with graduate students and teachers, it was obvious that the groups had similar overall challenges; although the extent of the different challenges differed between the groups, and they ranged from home and social environment to actual teaching, working and examinations. Whether working from home was beneficial depended on the physical work environment, as well as whether the person had others at home or not. To be alone is difficult if it is not chosen, and [6] stressed that being in quarantine can have long lasting effects. The move from in-person teaching to online teaching went relatively smoothly, and is probably partly due to a high availability of digital devices and internet access in Sweden; although the quality can differ [30] and potentially create unfairness. To provide appropriate and fair online exams without possibilities to cheat is still a major challenge, and different systems might need to be developed and implemented in the future to accommodate specific needs. As certain parts of society have opened up, practical parts in the studies are allowed to be done in schools and on campus, which facilitates these learning situations. What remains to be solved is how to plan research projects and change graduate projects that demand in-person meetings. This 
is a challenge that should be considered when planning projects in the future, as a similar situation could potentially occur.

The third research question concerned the challenges of switching from in-person teaching and testing to online teaching and testing. Several challenges were addressed, but perhaps the most difficult one to solve is how to ensure fair testing while making sure that personal integrity is not violated. If one decides on remote testing, a possibility for creating a fairer testing environment is to create test centers or rooms in universities and schools where tests can be conducted for those who lack resources, and where remote proctoring can be used. This would create a more equal situation between different groups. If one would pursue online teaching and testing, one may also encourage schools to provide digital devices to each student, even in lower grades (e.g., one Swedish northern community gave computers to all pupils in grade 4 , and another community gave all pupils computers from grade 1 , instead of grade 6), and to see the advantages of computerized tests over paper and pencil tests in, for example, learning geography [36]. A downside is that the cost of providing devices to a large number of students has to be taken from other parts of the students' education. The main advantage, however, is that all students would have the same tools and, thus, it would facilitate a fairer education.

\section{Conclusions}

The overall conclusion from this study is that the pandemic has forced a number of major changes, and several challenges that need to be addressed have come to the surface. COVID-19 has changed large-scale assessments in terms of the administration of the SweSAT, national tests, and how exams are taken at the universities, and it will probably influence these areas in several years to come. Some changes have been positive, but others are still to be discussed, as not all of them are desirable from an educator perspective or from a personal integrity perspective. COVID-19 has forced educators and testing institutions to reconsider how, when, and where assessments are taken. Teachers and students have learnt how to work remotely, which will probably be useful even when life goes back to normal.

There are some limitations with our research. First, the pandemic is still ongoing and, although some universities and upper-secondary schools have opened up to some extent, a large mass of students is still receiving their instructions and exams online. What the really good examples are is still to be decided. Second, whether the students learn more or less due to online learning needs to be examined, but it is too early to examine this. During 2022 , the national tests will probably be taken, and one can then compare the students' results from those taken before the pandemic.

In the future, it would also be interesting to conduct a large survey of how students on different levels and teachers have perceived working from home, and what could be improved if we have a similar situation in the future. It would also be interesting to study the effect of teaching format (online class versus in-person class) on students' knowledge.

Author Contributions: Conceptualization, M.W., P.-E.L. and A.L.P.; Funding acquisition, M.W.; Investigation, M.W., P.-E.L. and A.L.P.; Methodology, M.W., P.-E.L. and A.L.P.; Project administration, M.W.; Resources, M.W.; Validation, M.W., P.-E.L. and A.L.P.; Writing—original draft, M.W., P.-E.L. and A.L.P.; Writing-review \& editing, M.W., P.-E.L. and A.L.P. All authors have read and agreed to the published version of the manuscript.

Funding: This research was funded by the Swedish Research Council grant number 2015-02160.

Institutional Review Board Statement: Ethical review and approval were waived for this study, due to no sensitive personal data was collected.

Informed Consent Statement: Not applicable.

Data Availability Statement: Not applicable. 
Conflicts of Interest: The authors declare no conflict of interest. The funders had no role in the design of the study; in the collection, analyses, or interpretation of data; in the writing of the manuscript, or in the decision to publish the results.

\section{References}

1. Camara, W. Never let a crisis go to waste: Large-Scale assessment and the response to COVID-19. Educ. Meas. Issues Pract. 2020, 39, 10-18. [CrossRef]

2. Mishra, L.; Guptha, T.; Shree, A. Online teaching-learning in higher education during lockdown period of COVID-19 pandemic. Int. J. Educ. Res. Open 2020, 1. [CrossRef]

3. Basilaia, G.; Kvavadze, D. Transition to online education in schools during a SARS-CoV-2 Coronavirus (COVID-19) Pandemic in Georgia. Pedagog. Res. 2020, 5, em0060. [CrossRef]

4. Sintema, E.J. Effect of COVID-19 on the performance of grade 12 students: Implications for STEM education. Eurasia J. Math. Sci. Technol. Educ. 2020, 16, em1851. [CrossRef]

5. $\quad$ Brazendale, K.; Beets, M.W.; Weaver, R.G.; Pate, R.P.; Turner-McGrievy, G.M.; Kaczynski, A.T.; Chandler, J.L.; Bohnert, A.; von Hippel, P.T. Understanding differences between summer vs. school obesogenic behaviors of children: The structured days hypothesis. Int. J. Behav. Nutr. Phys. Act. 2017, 14, 100. [CrossRef]

6. Brooks, S.K.; Webster, R.K.; Smith, L.E.; Woodland, L.; Wessely, S.; Greenberg, N.; Rubin, G.J. The psychological impact of quarantine and how to reduce it: Rapid review of the evidence. Lancet 2020. [CrossRef]

7. Prop 2017/18:14. Nationella prov-rättvisa, likvärdiga, digitala; National Tests-Fair, Equal, Digital; Utbildningsdepartementet: Stockholm, Sverige, 2017; Available online: https:/ /www.regeringen.se/4a63bd/contentassets / 4d631707555d41318fc5d8e4eeb3 9ac2/nationella-prov--rattvisa-likvardiga-digitala-prop.-20171814.pdf (accessed on 9 December 2020).

8. Skolverket. Nationella Prov I Grundskolan. National Tests in Compulsory School; Skolverket: Stockholm, Sverige, 2020; Available online: https:/ / www.skolverket.se/undervisning/grundskolan/nationella-prov-i-grundskolan (accessed on 10 December 2020).

9. Skollag 2010:800. The Education Act 2010:800; Sveriges riksdag: Stockholm, Sverige, 2010; Available online: https://www. riksdagen.se/sv/dokument-lagar/dokument/svensk-forfattningssamling/skollag-2010800_sfs-2010-800 (accessed on 10 December 2020).

10. Skolverket. Sökande och antagna till gymnasieskolan läsåret 2019/20; Applicants and Admitted to Upper-Secondary School, School Year 2019/2020; Skolverket: Stockholm, Sverige, 2019; Available online: https: / / www.skolverket.se/getFile?file=4976 (accessed on 5 January 2021).

11. Folkhälsomyndigheten. Information till Skola och Förskola om den nya Sjukdomen Covid-19; Information to Schools and Preschools about the New Disease Covid-19; Folkhälsomyndigheten: Stockholm, Sverige, 2020; Available online: https: / / www.folkhalsomyndigheten.se/smittskydd-beredskap/utbrott/aktuella-utbrott/covid-19/verksamheter/information-tillskola-och-forskola-om-den-nya-sjukdomen-covid-19/ (accessed on 12 December 2020).

12. Buonsenso, D.; de Rose, C.; Moroni, R.; Valentini, P. SARS-CoV-2 Infections in Italian Schools: Preliminary Findings after One Month of School Opening during the Second Wave of the Pandemic. Front. Pediatr. 2020, 8, 615894. [CrossRef] [PubMed]

13. Ismail, S.A.; Saliba, V.; Bernal, J.A.L.; Ramsay, M.E.; Ladhani, S.N. SAES-CoV-2 infection and transmission in educational settings: Cross-sectional analysis of clusters and outbreaks in England. medRxiv 2020. [CrossRef]

14. Skolinspektionen. Gymnasieskolors Distansundervisning under Covid-19 Pandemin: Skolinspektionens Centrala Iakttagelser efter Intervjuer Med Rektorer; Distance Education in Upper-Secondary Schools during the Covid-19 Pandemic: Key Observations by the Swedish Schools Inspectorate after Interviews with Principals; Skolinspektionen: Stockholm, Sverige, 2020; Available online: https:/ / www.skolinspektionen.se/beslut-rapporter-statistik/publikationer/ovriga-publikationer/2020/gymnasieskolorsdistansundervisning-under-covid-19/ (accessed on 5 January 2021).

15. Skolverket. Undersökning av Frånvaro Bland Lärare, Barn och Elever-Uppföljning för April 2020; Investigation of Absence from Schools among Teachers, Children and Students-Follow-Up for April 2020; Skolverket: Stockholm, Sverige, 2020; Available online: https:/ / www.skolverket.se/download/18.266e4aa5171bb85dcd8f76/1589262222427/pdf6654.pdf (accessed on 5 January 2021).

16. Skolverket. Digital kompetens i förskola, skola och vuxenutbildning; Skolverkets uppföljning av den nationella digitaliseringsstrategin för skolväsendet 2018; Digital Competence in Preschool (Kindergarten), School and Adult Education. A Follow-Up by the National Agency of Education of the National Digitisation Strategy for the School System 2018; Skolverket: Stockholm, Sverige, 2019; Available online: https: / / www.skolverket.se/getFile?file=4041 (accessed on 4 January 2021).

17. Skolverket. PM-Slutbetyg i Grundskolan Våren 2020; PM-Final Grades in Compulsory School Spring 2020; Skolverket: Stockholm, Sverige, 2020; Available online: https:/ / www.skolverket.se/download/18.22df6cdd172a07d4e642228/1600768070605/pdf7301. pdf (accessed on 5 January 2021).

18. Backes, B.; Cowan, J. Is the Pen Mightier than the Keyboard? The Effect of Online Testing on Measured Student Achievement; Working Paper 190; National Center for Analysis of Longitudinal Data in Education Research: Arlington, VA, USA, 2018; Available online: https:/ / caldercenter.org/sites/default/files/WP\%20190.pdf?platform=hootsuite (accessed on 30 September 2020).

19. Lyrén, P.-E.; Wikström, C. Admissions Practices in Sweden. In Higher Education Admissions Practices: An International Perspective; Oliveri, M., Wendler, C., Eds.; Cambridge University Press: Cambridge, UK, 2020; pp. 203-216. [CrossRef] 
20. Universitetsläraren [The University Teacher]. Spelet som ledde till Karin Rödings avgång. The game that led to Karin Röding's resignation. Available online: https://universitetslararen.se/2020/09/17/spelet-som-ledde-till-karin-rodings-avgang/ (accessed on 15 December 2020).

21. Hoover, E. Testing Shakeup: Caltech Won't Consider ACT/SAT Scores for Next 2 Years; The Chronicle of Higher Education: Washington, DC, USA, 2020; Available online: https://www.chronicle.com/article/Testing-Shakeup-Caltech/248938 (accessed on 28 December 2020).

22. Universitets-och högskolerådet. Pilotstudie; Digitalisering av högskoleprovet; Pilot Study; Digitalization of the SweSAT; Universitetsoch högkolerådet: Stockholm, Sverige, 2019.

23. Engstrom, M.K. Så Många var Smittade på Universitetet. Available online: https://www.vk.se/2020-09-17/klart-sa-manga-varsmittade-pa-universitetet (accessed on 29 September 2020).

24. Troussas, C.; Krouska, A.; Sgouropoulou, A. Collaboration and fuzzy-modeled personalization for mobile game-based learning in higher education. Comput. Educ. 2020, 144, 103698. [CrossRef]

25. Hollister, K.; Berenson, M. Proctored versus unproctored online exams: Studying the impact of exam environment on student performance. Decis. Sci. J. Innov. Educ. 2009, 7, 271-294. [CrossRef]

26. Fask, A.; Englander, F.; Wang, S. Do online exams facilitate cheating? An experiment designed to separate possible cheating from the effect of the online test taking environment. J. Acad. Ethics 2014, 12, 101-112. [CrossRef]

27. Karlsson, M.; (Umeå University, Umeå, Sweden); Wiberg, M.; (Umeå University, Umeå, Sweden). Personal Communication, 2020.

28. Universitetsläraren. The University Teacher Ingen Allmän Förlängning att Vänta för Doktorander. No General Extension of Study Time for PhD Students. Available online: https: / universitetslararen.se/2020/12/10/ingen-allman-forlangning-att-vantafor-doktorander/ (accessed on 13 January 2021).

29. IEA. TIMSS 2015 International Database. From the IEA Website. Available online: https://www.iea.nl/index.php/data-tools / repository (accessed on 10 June 2017).

30. Svenskarna och Internet 2020. The Swedish People and Internet. Available online: https:/ /svenskarnaochinternet.se/rapporter/ svenskarna-och-internet-2019/allmant-om-internetutvecklingen/ (accessed on 13 January 2021).

31. Karay, Y.; Schauber, S.K.; Stosch, C.; Schuttpelz-Brauns, K. Computer vs. paper-Does it make any difference in test performance? Teach. Learn. Med. 2015, 27, 57-62. [CrossRef] [PubMed]

32. Foster, D.; Layman, H. Online Proctoring Systems. Caveon Test Security. 2013. Available online: https://www.caveon.com/wpcontent/uploads/2014/03/Online-Proctoring-Systems-Compared-Mar-13-2013.pdf (accessed on 29 September 2020).

33. Chin, M. Exam Anxiety: How Remote Test-Proctoring is Creeping Students Out. The Verge. Available online: https://www theverge.com/2020/4/29/21232777/examity-remote-test-proctoring-online-class-education (accessed on 29 September 2020).

34. Integritetsskyddsmyndigheten. Digital Undervisning. Digital Teaching. Available online: https://www.imy.se/vagledningar/ skolor-och-forskolor/digital-undervisning/ (accessed on 6 April 2021).

35. Skolverket. Analyser av likvärdig betygssättning i gymnasieskolan; Jämförelser mellan kursbetyg och kursprov; Analyzes of Equal Grades in Upper-Secondary Schools. Comparison between Course Grades and Course Tests; Skolverket: Stockholm, Sverige, 2020; Available online: https://www.skolverket.se/download/18.1a8151cc170ae4599bce10/1585902805741/pdf6564.pdf (accessed on 11 March 2021).

36. Shephers, I.D.H. Teaching geography with the computer: Possibilities and problems. J. Geogr. High. Educ. 2007, 9, 3-23. [CrossRef] 